\title{
Hvorfor faller eldre?
}

\section{Det er flere årsaker til at eldre faller. Hvilke forhold $\varnothing$ ker risikoen for fall?}

Torgeir Bruun Wyller

Professor i geriatri og overlege

Universitetet i Oslo og Geriatrisk avdeling, Oslo universitetssykehus

\begin{tabular}{lll}
\hline Geriatri & Fall & Hidre \\
\hline
\end{tabular}

\section{Hovedbudskap}

Fall hos eldre representerer et betydelig helseproblem. En rekke medisinske årsaker kan ligge bak en falltendens hos eldre, og ofte er det flere årsaker som virker sammen. Eldre med falltendens trenger derfor alltid en grundig medisinsk unders $\varnothing$ kelse. Hvis falltendensen har oppstått eller forverret seg raskt, trenger pasienten øyeblikkelig hjelp.

De fleste fallene får ikke så alvorlige konsekvenser, men mange fall fører likevel til skader. Mange eldre som har falt, blir liggende lenge uten å klare å komme opp igjen, og mange eldre er svært redde for å falle og innskrenker derfor aktivitetsnivået sitt.

Blant de mest alvorlige konsekvensene finner vi hodeskader og hoftebrudd. Hoftebrudd medfører en rekke komplikasjoner, en ikke ubetydelig dødelighet og svært ofte et varig svekket funksjonsnivå. Ikke sjelden er hoftebrudd den utløsende faktoren som gjør at en pasient havner på sykehjem for resten av livet.

Tiltak for å forebygge fall blir ofte sterkt konsentrert om fallfeller i hjemmet, strøing av fortau, belysning, støttehåndtak med mer. Disse tiltakene er viktige. 
Men dessverre forsømmes det ofte å vurdere om det er forhold ved personens helse som fører til $\varnothing \mathrm{kt}$ fallrisiko, og som kan korrigeres. Ofte er det det, men dessverre går svært mange eldre rundt med høy fallrisiko som det kunne vært gjort noe med, men som ingen tar tak i.

\section{Akutt økende falltendens må undersøkes}

Når gamle mennesker brått, fra timer til dager, får sterkt $\varnothing$ kende problemer med å holde seg på beina, skyldes det ofte akutt sykdom. Sammen med delirium er brått $\varnothing$ kende falltendens ofte en del av det syndromet som gjerne går under navnet «akutt funksjonssvikt».

Gamle som blir akutt syke, mister svært ofte evnen til å mestre ting de ellers kan, som å tenke klart (de får delirium) eller holde seg oppreist (de faller). Nyoppstått falltendens er derfor et viktig, men veldig uspesifikt symptom. Det forteller oss at pasienten kan være akutt syk, men det sier ingenting om hva som feiler vedkommende.

Ved akutt sykdom får gamle ofte sparsomt med organrettede symptomer. De kan for eksempel ha hjerteinfarkt uten brystsmerter, lungeemboli uten tung pust, alvorlige infeksjoner uten feber eller blindtarmsbetennelse uten magesmerter.

Derfor skal uspesifikke symptomer som brått økende falltendens avstedkomme en grundig medisinsk unders $\varnothing$ kelse.

\section{Flere forhold kan bidra til kronisk falltendens}

En rekke forhold kan $\varnothing$ ke risikoen for fall hos eldre. Grensen mellom årsaker til fall og risikofaktorer for fall er uskarp. Når man utreder gamle med falltendens, finner man av og til én dominerende årsak som kan behandles, og dermed slutter pasienten å falle. Det er moro å gjøre slike funn, men det skjer ikke så ofte.

Mye vanligere er det at pasienten har flere risikofaktorer som $\emptyset$ ker risikoen for fall. Noen lar seg korrigere, andre ikke. Hvis vi korrigerer det vi kan korrigere, vet vi at pasienten høyst sannsynlig kommer til å oppleve færre fall i fremtiden enn om vi ikke gjør noe, men ofte får vi ikke helbredet falltendensen fullstendig. 


\section{Legemidler}

Svært mange legemidler disponerer for fall - via ulike mekanismer. Hvis pasienten bruker flere slike legemidler, vil fallrisikoen naturligvis bli tilsvarende større. Dette gjelder alle legemidler som senker blodtrykket, både de som brukes som blodtrykksmedisiner, og de som brukes for andre formål.

Eksempler på blodtrykkssenkende legemidler er kalsiumblokkere, betablokkere, alfablokkere (som brukes mot prostatabesvær), diuretika, A2-blokkere, ACE-hemmere og langtidsvirkende nitropreparater.

Videre vil alle legemidler som virker sløvende på hjernen, gi $\varnothing \mathrm{kt}$ risiko for fall. Dette gjelder alle angstmidler, sovemidler, antipsykotika, antidepressiver, opioidanalgetika - inkludert kodein i Paralgin Forte - og antiepileptika.

\section{$\equiv$ «Svært mange legemidler disponerer for fall.»}

Diabetesmedisiner kan føre til falltendens hvis blodsukkeret blir for lavt. En rekke forskjellige legemidler, blant annet epilepsimidler, psykofarmaka, diuretika, A2-blokkere og ACEhemmere, har tendens til å gi hyponatremi, som i sin tur gir større tendens til å falle. Fordi underernæring disponerer for fall, vil også legemidler som gir redusert appetitt, indirekte kunne gi falltendens.

Konklusjonen er at hos en eldre pasient som har tendens til å falle, må man gå kritisk gjennom hele medisinlisten for å vurdere hva pasienten har av risikomedikamenter, og om noen av dem bidrar i så stor grad til fallfare at de bør seponeres, dosejusteres eller byttes ut med noe annet.

\section{Ernæringssvikt}

Når personer tar inn mindre energi enn de forbruker, brukes først energilageret opp i form av fett. Deretter vil kroppen begynne å forbrenne protein for å skaffe nok energi til hjernen og de grunnleggende livsprosessene.

Kroppens viktigste proteinlager er muskulaturen, særlig de store musklene i lårene og setet. Eldre som er i ernæringsmessig underskudd, vil derfor rett og slett forbruke musklene sine som energireserve. Dermed blir de svakere og faller lettere. 
Fall får dessuten ofte mer alvorlige konsekvenser hos tynne.

De har dårligere «polstring», og siden fettvevet er det

viktigste produksjonsstedet for $\varnothing$ strogen etter klimakteriet, har tynne postmenopausale kvinner også $\varnothing \mathrm{kt}$ risiko for osteoporose.

\section{Kardiologiske årsaker}

Lavt blodtrykk og ortostatisk hypotensjon er sterke risikofaktorer for å falle. Av og til skyldes lavt blodtrykk legemidler, som forklart ovenfor, og da kan man vurdere å endre legemiddellisten.

Hos gamle som har lavt blodtrykk eller ortostatisme (se faktaboks) uten å bruke blodtrykkssenkende legemidler, kan man gi råd om elastiske strømper og tilstrekkelig inntak av vann og salt, eksempelvis en halv liter Farris mellom frokost og lunsj hver dag. I meget sjeldne tilfeller kan man gi råd om blodtrykkshevende medisiner.

Videre kan både for rask puls, for eksempel dårlig regulert atrieflimmer, og for langsom puls, eksempelvis på grunn av atrioventrikulært blokk (AV-blokk), føre til falltendens. Det samme kan enkelte klaffesykdommer, særlig aortastenose.

\section{Ortostatisme}

Ortostatisk hypotensjon er fall i systolisk blodtrykk på 20 mmHg eller mer og/eller fall i diastolisk blodtrykk på 10 mmHg eller mer når man reiser seg fra sittende eller liggende til stående stilling. Det er svært viktig å registrere om blodtrykksfallet er ledsaget av symptomer eller ikke. Typiske symptomer er svimmelhet, at det svartner for øynene og en følelse av å ville besvime.

Kilde: Store medisinske leksikon

\section{Synkope}

Mennesker som besvimer, har ofte hukommelsestap om hendelsen. Hvis en gammel og litt ust $\varnothing$ person plutselig finner seg selv liggende på gulvet, er det helt logisk at vedkommende tenker: «Jeg snublet sikkert!» Men det kan faktisk tenkes at vedkommende har besvimt.

Hvis ingen har sett det som skjedde, er det ofte ikke lett å bringe mekanismen på det rene. Hvis den som har falt, husker godt hva som skjedde og for eksempel kan beskrive at hun eller han mistet balansen og kan beskrive måten hun eller han landet på, har vedkommende antakelig ikke vært bevisstløs. 
Men hvis beskrivelsen er uklar, og særlig hvis pasienten har skadet hodet eller armene i fallet, kan man få mistanke om synkope, altså kortvarig bevissthetstap. Pasienter som besvimer, «klasker» ofte hardt i bakken og slår ut tenner, brekker nesen eller annet, mens de som faller av andre årsaker, oftere «siger sammen» eller faller på setet eller hoften.

Synkope kan i sin tur ha mange årsaker. Hos unge er «vanlig besvimelse» nesten alltid ufarlig, men hos eldre ligger det oftere alvorlig sykdom bak. Årsakene til synkope er mange av de samme som er beskrevet under kardiologiske årsaker til fall i avsnittet over.

Hvis man mistenker at en eldre person har falt på grunn av synkope, er det som regel grunn til rask videre utredning.

\section{Epilepsi}

Epileptiske anfall kan også «maskere» seg som et fall. Det er ikke sjelden at epilepsi oppstår første gangen i høy alder hos en person som ikke har hatt sykdommen tidligere. Da trenger det ikke være som et klassisk generalisert tonisk-klonisk anfall (GTK-anfall, se faktaboks). De ufrivillige bevegelsene kan av og til forekomme bare i én del av kroppen, og er av og til lite synlige.

\section{三 «pileptiske anfall kan også 'maskere’ seg som et fall.»}

Noen ganger kan epilepsianfall være vanskelig å skille fra synkope. Et hjelpemiddel for å skille de to fra hverandre er at pasienter som synkoperer, vanligvis våkner raskt og helt fullstendig opp, og da er de helt «seg selv» igjen.

Pasienter med epilepsi, derimot, har ofte en postiktal fase tiden etter et anfall - som er preget av tretthet og forvirring. Hos unge med epilepsi varer denne fasen ofte bare noen få minutter, men hos eldre kan den vare mange timer og av og til flere dager.

Det er svært nyttig å oppdage de tilfellene av fall som skyldes epilepsi, siden korrekt medikamentell behandling kan stoppe anfallene. 
Generaliserte tonisk-kloniske anfall er den mest alvorlige anfallsformen ved epilepsi og starter typisk med plutselig bevissthetstap etterfulgt av tilstiving av hele kroppen, av og til med skrik og tungebitt.

Kilde: $\underline{\text { Helsebiblioteket.no }}$

\section{Parkinsonisme}

Parkinsonisme er et syndrom som kjennetegnes av skjelvinger, treghet i muskulaturen (rigiditet), langsomme bevegelser (hypokinesi) og svekkede posturale reflekser. Ved svekkede posturale reflekser flytter pasienten ikke beinet automatisk når han eller hun er i ferd med å ta overbalanse, slik det er normalt å gjøre.

Parkinsonisme kan skyldes Parkinsons sykdom, andre hjernesykdommer eller være en bivirkning av antipsykotiske legemidler. Det er ikke vanskelig å skjønne at parkinsonisme er en viktig risikofaktor for fall, for disse pasientene beveger seg sakte og klarer ikke å «fote seg» i tide hvis de holder på å falle.

Hos ellers friske personer er det ikke så vanskelig å kjenne igjen parkinsonistiske symptomer. Men gamle kan være trege og ubevegelige også av andre årsaker, slik som artrose, artritt eller kompresjonsbrudd, og da kan det av og til kamuflere parkinsonismen.

Hvis pasienten har Parkinsons sykdom, har de ofte svært god effekt av legemidler som inneholder levodopa (Madopar, Sinemet eller Stalevo), og derfor er det meget nyttig å stille denne diagnosen.

I tilfellene der parkinsonisme er en legemiddelbivirkning, må man gjøre hva man kan for å få seponert det utløsende legemiddelet. Parkinsonisme av andre årsaker kan være vanskelig å behandle.

\section{Polynevropati}

Polynevropati fører til dårlig ledningsevne i nervene, som oftest mest i beina. Vanlige årsaker er diabetes mellitus og overforbruk av alkohol, men nevropati kan også ha en lang rekke andre årsaker. Hvis nevropatien rammer de motoriske nervene, blir pasienten svak i muskulaturen. 
Hvis sykdommen rammer de sensoriske nervene, får pasienten dårlig følesans, ofte svært uttalt i fotsålene. Dermed kjenner ikke pasienten hvordan kroppens vektfordeling mot underlaget er: om han eller hun er i fare for å falle bakover eller forover. Både motorisk og sensorisk polynevropati gir derfor $\varnothing \mathrm{kt}$ tendens til å falle.

Det finnes ingen generell behandling av polynevropati, men man må prøve å behandle årsaken. Ved diabetisk polynevropati vil det ofte være nyttig å regulere blodsukkeret bedre. Ved alkoholisk nevropati vil symptomene kunne bli bedre dersom pasienten klarer å redusere alkoholforbruket eller helst slutte helt å drikke.

\section{Demens}

Moderat til alvorlig demens er en kraftig risikofaktor for fall av minst tre årsaker. For det første vil personer med demens ofte opptre ukritisk, glemme å holde seg fast eller glemme at de er avhengig av rullator.

For det andre rammer demens ofte romretningssansen, slik at pasienten har vanskeligere for å bed $\varnothing$ mme avstand, se dybder med mer. Dermed vil personen med demens ha lett for å snuble i kanter og trappetrinn eller bomme på stolen når vedkommende skal sette seg.

For det tredje rammer demens ikke bare kognitive funksjoner, som hukommelse og romretningssans, men også motoriske funksjoner. Personer med alvorlig demens har ofte ganske parkinsonistiske bevegelser. Dermed får de $\varnothing \mathrm{kt}$ fallrisiko på samme måte som beskrevet i avsnittet om parkinsonisme.

\section{三 $\ll$ Moderat til alvorlig demens er en kraftig risikofaktor for fall.»}

Hvis en person med kjent, alvorlig demens faller til stadighet, er det derfor i mange tilfeller demensen i seg selv som er den viktigste årsaken. Men det er ingen grunn til ikke å vurdere om det også kan foreligge andre årsaker.

Kanskje vedkommende i tillegg bruker legemidler, slik som blodtrykksmedisiner, som $\varnothing$ ker tendensen til å falle? Da vil disse to forholdene forsterke hverandres effekt.

Demensen kan vi ikke helbrede, men da er det desto st $\varnothing$ rre grunn til å gå kritisk gjennom andre forhold som kan bidra til falltendens, og korrigere det som kan korrigeres. 


\section{Sykdommer i likevektsorganet}

Av og til er det sykdommer i balanseorganet i det indre $\varnothing$ ret som gjør at pasienten faller, for eksempel «krystallsyke» (BPPV - benign paroksysmal posisjonsvertigo) eller Ménières sykdom.

Pasienter med slike sykdommer har ofte en uttalt svimmelhet, altså en bevegelsesillusjon der de føler at verden snurrer rundt eller går i bølger rundt dem.

\section{三 «Det er viktig å spørre spesifikt hva pasienten mener dersom han eller hun klager over 'svimmelhet'.»}

Det er viktig å spørre spesifikt hva pasienten mener dersom han eller hun klager over «svimmelhet», for mange bruker dette ordet rett og slett om det å føle at man er på nippet til å falle - det vi i helsevesenet vanligvis kaller for ust $\varnothing$ het. Ustøhet skyldes som regel sykdommer andre steder enn i likevektsorganet.

Men hvis pasienten er «ekte svimmel», er det mer sannsynlig med en sykdom i likevektsorganet. Hvis et slikt symptom er oppstått helt akutt, kan det også skyldes hjerneslag i lillehjernen eller noen av nerveforbindelsene til eller fra lillehjernen. Slike pasienter trenger umiddelbar behandling.

\section{Svekket balanse og svake muskler i beina}

Svekket balanse og svake muskler i beina er nok den aller vanligste risikofaktoren for fall hos eldre. Alle vet at muskler blir svake om de ikke brukes. Men mange vet ikke at det samme gjelder balanseevnen. Eldre som rører seg lite, mister både muskelkraft og «balansekraft», og får $\emptyset \mathrm{kt}$ fallrisiko.

Det gode budskapet er imidlertid at begge deler lar seg trene, uansett hvor gammel man er. Sterkere bein og en mer trent balanse gir klart redusert fallrisiko.

Men det er ikke så lett å trene balansen på egen hånd, for slik trening innebærer at man må utfordre balansen, altså sette seg i en situasjon der man føler man er nær på å falle. De fleste mennesker vil naturlig prøve å unngå det.

Mange norske kommuner har de senere årene startet gruppebasert styrke- og balansetrening for eldre. Slike tilbud er som regel meget gode, som enda flere eldre burde få sjansen til å delta på. 


\section{Noen tilfeller bør henvises videre}

Kompliserte tilfeller kan henvises videre til

spesialisthelsetjenesten, for eksempel til en geriatrisk poliklinikk. Geriatrisk avdeling ved Oslo universitetssykehus (OUS) har egen fallpoliklinikk (1) med særlig kompetanse på utredning av pasienter med falltendens av ukjent årsak. Det går an å henvise til vår fallpoliklinikk også for pasienter som ikke har OUS som lokalsykehus.

\section{Referanser}

Hele teksten er basert på Wyller TB. Geriatri - en medisinsk lærebok. 3. utg. Oslo: Gyldendal; 2020

1. Smebye KL, Granum S, Wyller TB, Mellingsæter M. Medisinske funn i en tverrfaglig geriatrisk fallpoliklinikk.

Tidsskr Nor Legeforen. 2014;134:705-9. 